\title{
Upaya Meningkatkan Keterampilan Proses Sains dan Hasil Belajar Siswa melalui Penerapan Model Discovery Learning di Kelas X IPA 3
}

\author{
Ega Oktofika, Rosane Medriati, dan Eko Swistoro \\ Program Studi S1 Pendidikan Fisika, Jurusan Pendidikan MIPA, \\ Fakultas Keguruan dan Ilmu Pendidikan, Universitas Bengkulu \\ Jalan Raya Kandang Limun No. Bengkulu 38123 \\ Email: Oktofikaega@Gmail.Com
}

\begin{abstract}
ABSTRAK
Penelitian ini bertujuan untuk mendeskripsikan peningkatan aktivitas belajar siswa, keterampilan proses sains siswa (KPS) dan hasil belajar siswa melalui penerapan model Disecovery Learning. Penelitian ini termasuk penelitian tindakan kelas. Subjek penelitian ini adalah seluruh siswa kelas X IPA 3 yang berjumlah 30 siswa. Hasil penelitian menunjukkan bahwa nilai rata-rata aktivitas siswa pada siklus I termasuk dalam kategori cukup, kemudian menjadi baik pada siklus II dan semakin baik pada siklus III. Keterampilan proses sains yang diuji adalah keterampilan mengajukan pertanyaan, merumuskan hipotesis, merencanakan percobaan, menafsirkan dan berkomunikasi. Dari kelima keterampilan yang diuji, persentase peningkatan tertinggi dari siklus ke siklus adalah pada keterampilan merumuskan hipotesis, sedangkan keterampilan yang paling dikuasai siswa adalah pada keterampilan mengajukan pertanyaan. Hasil belajar siswa pada aspek pengetahuan secara keseluruhan terjadi peningkatan ketuntasan belajar siswa secara klasikal dari siklus I sampai siklus III. Pada siklus I diperoleh daya serap siswa sebesar 70,5\% dan ketuntasan belajar siswa sebesar 63,3\% (belum tuntas), meningkat pada siklus II diperoleh daya serap siswa sebesar 76,5\% dan ketuntasan belajar siswa sebesar $80 \%$ (tuntas), dan meningkat lagi pada siklus III diperoleh daya serap siswa sebesar 83,6 \% dan ketuntasan belajar siswa sebesar $100 \%$ (tuntas). Berdasarkan hasil penelitian dapat disimpulkan bahwa melalui penerapan model Discovery Learning dapat meningkatkan keteampilan proses sains dan hasil belajar siswa.
\end{abstract}

Kata kunci : Discovery Learning, aktivitas belajar, keterampilan proses sains, hasil belajar.

\begin{abstract}
This research was aimed to describe an enhancement of students' learning activities, students' science process skills and students' learning outcomes through model application of Discovery Learning. This research includes classroom action research. The subject this research was all students in X Science 3 with the total of 30 students.. The finding of this research indicated that the average values of students' activities in cycle I was categorized as enough, then became good in cycle II, and better in cycle III. Science process skills which were examined was the skills to propose a question, formulate hyphotheses, plan an experiment, interpret, and communicate. From those five skills examined, the highest enhancement percentage from cycle to cycle was on the skill of formulating hyphotheses, while the skill that mostly mastered by students was on the skill of proposing a question. The students' learning outcomes on the whole knowledge aspects were any enhancement of students' learning mastery classically from cycle I to cycle III. At the cycle I, it was obtained the students' absorption of $70.5 \%$ and students' learning mastery of $63.3 \%$ (incomplete), increased at the cycle II which was obtained the students' absorption of $76.5 \%$ and students' learning mastery of $80 \%$ (complete), and increased again at the cycle III which was obtained the students' absorption of 83.6\% and students' learning mastery of $100 \%$ (complete). From the research findings, it can be concluded that through the model application of

Discovery Learning can enhance the science process skills and students' learning outcomes.
\end{abstract}

Keywords: Discovery Learning, learning activities, science process skills, learning outcomes.

\section{Pendahuluan}

Dalam Kurikulum 2013 terdapat model-model pembelajaran yang digunakan salah satunya adalah model discovery learning. Menurut Suryosubroto [1] discovery learning merupakan model pembelajaran yang melibatkan siswa mengarahkan kemampuannya sehingga lebih aktif dalam proses pembelajaran. Model discovery learning merupakan model pembelajaran yang melibatkan siswa dalam melakukan kegiatan yang mampu mengembangkan keterampilan proses sains, dimana siswa berperan aktif dalam menemukan 
dan menyelidiki tentang suatu konsep sehingga memperoleh pengetahuan dari hasil temuan mereka sendiri [2]. Keterampilan proses sains merupakan keterampilan yang digunakan dalam menemukan dan mengembangkan konsep atau teori ataupun prinsip [3].

Berdasarkan observasi proses pembelajaran yang dilakukan di kelas X IPA 3 pada bulan Agustus 2017, secara umum perangkat pembelajaran yang digunakan sudah mengacu pada Kurikulum 2013. Namun terdapat beberapa poin penting yang ditemukan pada saat proses pembelajaran berlangsung. Guru kurang melibatkan siswa dalam proses pembelajaran sehingga siswa cenderung mendengarkan daripada memberi pendapat, guru cenderung menjelaskan konsep dan contoh soal saja sehingga jarang melakukan kegiatan percobaan. Hal tersebut menimbulkan beberapa permasalahan, yaitu (1) aktivitas belajar siswa masih kurang, yaitu hanya 23,4 \% atau 7 dari 30 siswa yang bertanya dan memberi pendapat, (2) kurangnya keterampilan proses sains yang dimiliki siswa, indikator yang ada pada keterampilan proses sains terlihat siswa belum memiliki keterampilan proses sains dalam melakukan percobaan seperti, mengajukan pertanyaan dan merumuskan hipotesis berdasarkan hasil pengamatan, merencanakan percobaan dan menggunakan alat/bahan siswa mengalami kesulitan dan kebingungan dalam melakukan percobaan sederhana, selain itu dalam merumuskan hipotesis siswa kurang tepat mengenai konsep yang dipelajari serta kurangnya kemampuan siswa dalam mengkomunikasikan hasil percobaan yang mereka peroleh , (3) hasil belajar siswa tergolong rendah, terlihat dari nilai ulangan harian pertama pada konsep besaran fisika dan pengukuran yaitu $30 \%$ atau 9 dari 30 siswa yang tuntas dan nilai ulangan harian kedua pada konsep vektor dimana 43,4 \% atau 13 dari 30 siswa yang tuntas berdasarkan kriteria ketuntasan minimal (KKM) sekolah yaitu 73.

Salah satu model pembelajaran yang dapat digunakan pada pembelajaran fisika yaitu model discovery learning. Model discovery learning merupakan model pembelajaran yang dapat mengarahkan siswa untuk memperoleh pengetahuan sendiri dari penemuannya. Dalam menerapkan model pembelajaran discovery learning terdapat kelebihan dan kekurangan. Menurut Marzono [4] terdapat beberapa kelebihan dalam menerapkan model discovery learning yaitu siswa dapat berpartisipasi aktif dalam pembelajaran, menumbuhkan sikap inquiry (mencari-temukan), memberikan wahana interaksi antar siswa, maupun siswa dan guru dan melatih kemampuan kognitif siswa untuk menemukan dan memecahkan masalah tanpa pertolongan orang lain.

Berdasarkan masalah di atas, maka rumusan masalah pada penelitian ini apakah melalui penerapan model Discovery Learning dapat meningkatkan aktivitas belajar, keterampilan proses sains dan hasil belajar siswa pada konsep usaha dan energi di kelas $\mathrm{X}$ IPA 3 SMA Negeri 10 Kota Bengkulu. Dari permasalahan di atas yang telah dirumuskan, maka penelitian ini bertujuan untuk mendeskripsikan peningkatan aktivitas belajar, keterampilan proses sains dan hasil belajar siswa pada konsep usaha dan energi di kelas $\mathrm{X}$ IPA 3 SMA Negeri 10 Kota Bengkulu.

\section{Metodologi penelitian}

Jenis penelitian ini penelitian tindakan kelas (PTK) atau classroom action research. Pada penelitian tindakan kelas terdapat empat tahapan. Subjek penelitian merupakan siswa kelas X IPA 3 SMA Negeri 10 Kota Bengkulu yang terdiri dari 30 siswa (12 laki-laki dan 18 perempuan). Penelitian ini dilakukan di kelas X IPA 3 SMAN 10 Kota Bengkulu pada bulan April-Mei 2018. Setiap siklus pada penelitian tindakan kelas terdiri dari empat tahapan yaitu (1) perencanaan, (2) pelaksanaan, (3) pengamatan dan (4) refleksi [5].

Instrumen penelitian yang digunakan yaitu lembar observasi aktivitas siswa dan guru, lembar tes keterampilan proses sains, dan lembar tes hasil belajar pengetahuan. Sebelum perangkat tes digunakan terlebih dahulu divalidasi oleh ahli, yaitu 1 orang dosen pendidikan fisika dan 2 orang guru mata pelajaran fisika. Data aktivitas siswa dan guru diperoleh dari hasil pengamatan yang menggunakan lembar observasi aktivitas siswa dan aktivitas guru 
sebagai pedoman keberhasilan proses pembelajaran pada satu siklus. Hasil observasi ini dianalisis dan dijadikan sebagai refleksi untuk siklus selanjutnya. Tes keterampilan proses sains menggunakan tes tertulis berupa soal uraian (essay) sebanyak 5 butir soal yang dilengkapi dengan kunci jawaban dan pedoman penskoran. Tes hasil belajar pengetahuan menggunakan tes tertulis berupa soal uraian (essay) sebanyak 3 butir soal yang dilengkapi dengan kunci jawaban dan pedoman penskoran.

Analisis data lembar observasi aktivitas siswa dan guru dalam penelitian ini ditunjukkan pada tabel 1.

Tabel 1. Interval Kategori Penilaian Aktivitas Siswa [6]

\begin{tabular}{ccc}
\hline No & Nilai Rentang & Prestasi Nilai \\
\hline $\mathbf{1}$ & $12-19$ & Kurang \\
$\mathbf{2}$ & $20-27$ & Cukup \\
$\mathbf{3}$ & $28-36$ & Baik \\
\hline
\end{tabular}

Untuk analisis data tes keterampilan proses sains dihitung menggunakan persamaan sebagai berikut :

$$
\text { Nilai }=\frac{\text { skor yang dijawab benar }}{\text { skor maksimal dari soal }} \times 100 \%
$$

Dari perhitungan nilai diatas, dapat ditentukan kriteria pencapaian kompetensi pada keterampilan proses sains, dapat dilihat pada tabel 2.

Tabel 2. Kriteria Persentase Pencapaian Kompetensi Keterampilan Proses Sains

\begin{tabular}{cc}
\hline Persentase (\%) & Kriteria \\
\hline $\mathbf{2 8 5}$ & Sangat baik (A) \\
$\mathbf{7 0 - 8 5}$ & Baik (B) \\
$\mathbf{5 6}-\mathbf{6 9}$ & Cukup (C) \\
$\mathbf{4 1}-\mathbf{5 5}$ & Kurang (D) \\
$\leq \mathbf{4 0}$ & Sangat kurang (E) \\
\hline
\end{tabular}

Data tes hasil belajar pada penelitian ini dianalisis menggunakan nilai rata-rata, standar deviasi, daya serap klasikal dan ketuntasan belajar klasikal.

a. Nilai rata-rata $(\bar{X})[7]$.

Dimana :

$$
\bar{X}=\frac{\sum X}{N}
$$

$\bar{X}=$ nilai rata-rata siswa

$\sum X=$ Jumlah nilai semua siswa

$\mathrm{N}=$ Jumlah siswa

b. Standar Deviasi [8]

$$
S=\frac{\sqrt{\sum(X-\bar{X})^{2}}}{N-1}
$$

Dimana :

$\mathrm{S}=$ Standar Deviasi

$\mathrm{X}=$ Nilai siswa

$\bar{X}=$ Nilai rata-rata siswa

$\mathrm{N}=$ Jumlah siswa 


\section{c. Daya Serap Klasikal}

Daya serap yaitu seberapa besar siswa menerima apa yang diajarkan oleh guru. Jadi semakin besar daya serap maka semakin banyak pula pelajaran yang dikuasai siswa.

$$
D S=\frac{N S}{S x N I} \times 100 \%
$$

Dimana :

DS = Daya serap siswa

NS = Jumlah nilai seluruh siswa

$\mathrm{NI}=$ Nilai ideal

$\mathrm{S}=$ Jumlah peserta tes.

\section{d. Ketuntasan Belajar Klasikal}

Dimana :

$$
\mathrm{KB}=\frac{\mathrm{N} \prime}{N} \times 100 \%
$$

$$
\begin{aligned}
\mathrm{KB}= & \text { Ketuntasan belajar secara } \\
& \text { klasikal } \\
\mathrm{N}^{\prime}= & \text { Jumlah siswa yang skornya } \\
& \text { mencapai KKM }
\end{aligned}
$$

\section{Hasil dan Pembahasan}

\subsection{Aktivitas Siswa}

Aktivitas belajar merupakan aktivitas yang terjadi pada saat proses pembelajaran yang didesain sehingga siswa dapat memperoleh tujuan yang akan dicapai [9]. Berdasarkan hasil penelitian yang telah dilakukan melalui penerapan model Discovery Learning terdapat peningkatan aktivitas belajar siswa pada setiap siklus seperti pada gambar 1 .

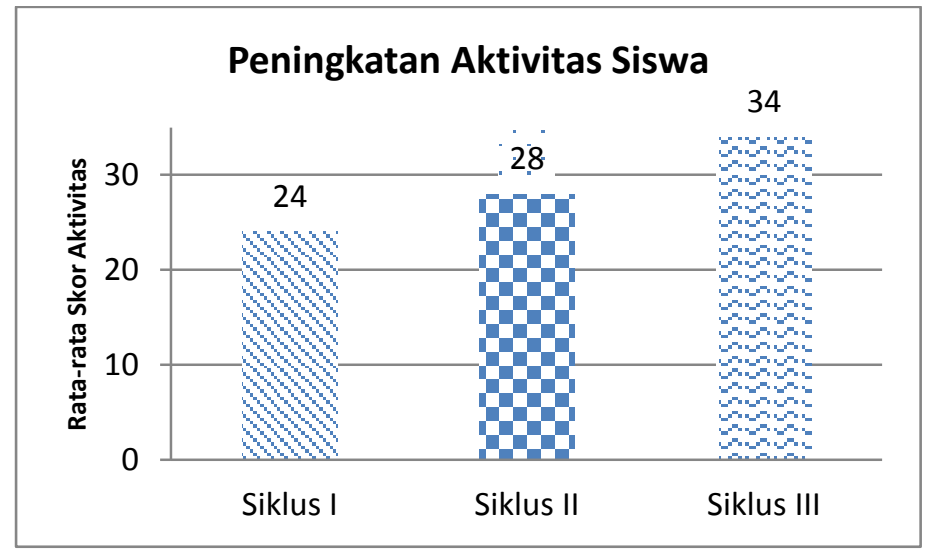

Gambar 1. Grafik Rata-rata Hasil Observasi Aktivitas siswa

Berdasarkan gambar 1 dapat dilihat bahwa aktivitas siswa mengalami peningkatan pada setiap siklusnya. Pada siklus I skor rata-rata yang diperoleh 24 dan dikategorikan cukup, untuk siklus II dan siklus III dikategorikan baik dengan skor rata-rata yang diperoleh 28 dan 34. Peningkatan ini disebabkan adanya perbaikan pada kekurangan-kekurangan yang dilakukan siswa dan guru pada setiap siklus, sehingga proses pembelajaran menjadi lebih baik. Peningkatan aktivitas belajar siswa dapat meningkatkan keterampilan proses sains dan hasil belajar siswa karena adanya keinginan siswa untuk belajar.

Berdasarkan uraian diatas dapat disimpulkan bahwa melalui penerapan model Discovery Learning dapat meningkatkan aktivitas belajar siswa. Hasil penelitian ini didukung oleh penelitian yang dilakukan [10] yang menyimpulkan bahwa melalui penerapan model Discovery Learning dapat meningkatkan aktivitas belajar siswa. 


\subsection{Keterampilan Proses Sains}

Keterampilan proses sains merupakan sesuatu yang sangat penting untuk dilatih dalam mengembangkan pengetahuan [11]. Pada penelitian ini, ada lima indikator yang diukur yakni mengajukan pertanyaan, merumuskan hipotesis, merencanakan percobaan, menafsirkan dan berkomunikasi. Kelima indikator keterampilan proses sains diukur melalui penilaian hasil tes yang diuji dengan lima butir soal, yang mana masing-masing soal mengukur satu indikator. Setiap indikator pada keterampilan proses sains diberi skor maksimum 20. Kemudian hasil dari penjumlahan skor masing-masing indikator dikategorikan sesuai dengan skala pencapaian keterampilan proses sains. Pencapaian keterampilan proses sains yang harus diperoleh pada penelitian ini, berada dikategori "cukup", "baik" dan "sangat baik".

Perbandingan persentase pencapaian keterampilan proses sains siswa dari siklus I sampai siklus III dapat dilihat pada gambar 2 .

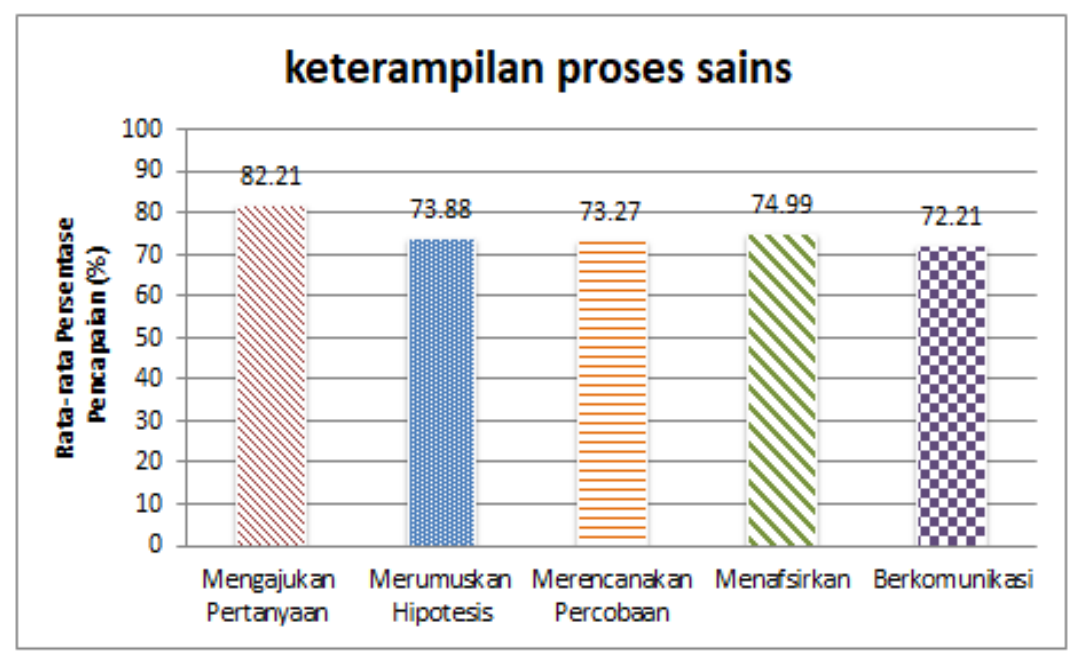

Gambar 2. Grafik rata-rata persentase pencapaian keterampilan proses sains pada tiga siklus

Berdasarkan gambar 2 terlihat bahwa rata-rata persentase pencapaian rata-rata kelas pada setiap indikator meningkat dikarenakan adanya refleksi yang dilakukan guru. Sehingga dari siklus I sampai siklus III selalu mengalami peningkatan. Pada setiap indikator keterampilan proses sains dikatakan baik dikarenakan rata-rata persentase pencapaian memperoleh nilai diatas $70 \%$.

Berdasarkan uraian diatas mengenai hasil penelitian keterampilan proses sains, dapat disimpulkan bahwa pembelajaran fisika melalui model Discovery Learning dapat meningkatkan keterampilan proses sains siswa. Hasil penelitian ini didukung oleh hasil penelitian [12] dan [13] yang menyimpulkan bahwa melalui penerapan model Discovery Learning dapat meningkatkan keterampilan proses sains siswa.

\subsection{Hasil Belajar}

Hasil belajar merupakan kemampuan yang dicapai siswa setelah mengikuti proses pembelajaran [14]. Hasil belajar pengetahuan siswa diperoleh dari nilai tes hasil belajar yang diberikan guru kepada siswa setelah siswa melakukan proses pembelajaran dengan menggunakan model Discovery Learning. Tes hasil belajar pengetahuan setiap siklus berupa tes uraian yang berjumlah 3 butir soal. Data hasil belajar pengetahuan siklus I, II dan II dapat dilihat pada tabel 3.

Tabel 3. hasil belajar pengetahuan siklus I, II, dan III 


\begin{tabular}{|l|c|c|c|}
\hline $\begin{array}{c}\text { Deskripsi Hasil } \\
\text { Belajar Siswa }\end{array}$ & Siklus I & Siklus II & Siklus III \\
\hline Nilai Terendah & 50 & 55 & 75 \\
\hline Nilai Terringgi & 90 & 95 & 100 \\
\hline Nilai Rata-rata & 70,5 & 76,5 & 83,6 \\
\hline Standar Deviasi & 10,93 & 8,62 & 6,81 \\
\hline Daya Serap (\%) & 70,5 & 76,5 & 83,6 \\
\hline Ketuntasan Belajar (\%) & 63,3 & 80 & 100 \\
\hline Kesimpulan & $\begin{array}{c}\text { Belum tuntas } \\
\text { secara } \\
\text { klasikal }\end{array}$ & $\begin{array}{c}\text { Tuntas secara } \\
\text { klasikal }\end{array}$ & $\begin{array}{c}\text { Tuntas secara } \\
\text { klasikal }\end{array}$ \\
\hline
\end{tabular}

Pada siklus I nilai terendah yang diperoleh siswa sebesar 50 dan nilai tertinggi sebesar 90 serta nilai rata-rata sebesar 70,5. Sedangkan ketuntasan belajar sebesar 63,3\% dan standar deviasi serta daya serap sebesar 70,5\%. Siswa dikatakan tuntas apabila $\geq 75 \%$ siswa memperoleh nilai Kriteria Ketuntasan Minimal (KKM) sebesar $\geq 73$. Dari data yang diperoleh, jumlah siswa yang tuntas sebanyak 19 siswa dan jumlah siswa yang belum tuntas sebanyak 11 siswa. Hal ini menunjukkan hasil belajar siswa dikatakan belum tuntas secara klasikal. Pada siklus II nilai terendah yang diperoleh siswa sebesar 55 dan nilai tertinggi sebesar 95 serta nilai rata-rata sebesar 76,5. Sedangkan ketuntasan belajar sebesar $80 \%$ dan standar deviasi serta daya serap sebesar 76,5\%. Siswa dikatakan tuntas apabila $\geq 75 \%$ siswa memperoleh nilai Kriteria Ketuntasan Minimal (KKM) sebesar $\geq 73$. Dari data yang diperoleh, jumlah siswa yang tuntas sebanyak 24 siswa dan jumlah siswa yang belum tuntas sebanyak 6 siswa. Hal ini menunjukkan hasil belajar siswa dikatakan tuntas secara klasikal dan mengalami peningkatan dari siklus I.

Pada siklus III nilai terendah yang diperoleh siswa sebesar 75 dan nilai tertinggi sebesar 100 serta nilai rata-rata sebesar 83,6. Sedangkan ketuntasan belajar sebesar $100 \%$ dan standar deviasi serta daya serap sebesar 83,6 \%. Siswa dikatakan tuntas apabila $\geq 75 \%$ siswa memperoleh nilai Kriteria Ketuntasan Minimal (KKM) sebesar $\geq 73$. Hal ini menunjukkan hasil belajar siswa dikatakan tuntas secara klasikal dan mengalami peningkatan dari siklus II. Hasil belajar siswa pada siklus III membuktikan bahwa siswa sudah memahami materi yang dipelajari dan mampu menjawab soal tes pengetahuan. Data peningkatan daya serap dan ketuntasan belajar secara klasikal dapat dilihat pada gambar 3.



Gambar 3. Grafik Daya Serap dan Ketuntasan Belajar Klasikal

Berdasarkan gambar 3 terlihat bahwa setiap siklus selalu mengalami peningkatan. Pada siklus I diperoleh daya serap sebesar 70,5\% dan ketuntasan belajar klasikal sebesar $63,3 \%$ Siswa dikatakan tuntas apabila $\geq 75 \%$ siswa memperoleh nilai Kriteria Ketuntasan 
Minimal (KKM) sebesar $\geq 73$. Hal ini menunjukkan hasil belajar siswa dikatakan belum tuntas secara klasikal. Ketidaktuntasan hasil belajar siswa pada siklus I dikarenakan siswa kurang teliti dalam menjawab pertanyaan dan masih mengalami kesulitan dalam mengerjakan soal perhitungan fisika, sehingga banyak siswa yang tidak tuntas.

Pada siklus II diperoleh daya serap sebesar 76,5 \% dan ketuntasan belajar klasikal sebesar $80 \%$. Siswa dikatakan tuntas apabila $\geq 75 \%$ siswa memperoleh nilai Kriteria Ketuntasan Minimal (KKM) sebesar $\geq 73$. Hal ini menunjukkan hasil belajar siswa dikatakan tuntas secara klasikal dan mengalami peningkatan dari siklus I.

Pada siklus III diperoleh daya serap sebesar 83,6 \% dan ketuntasan belajar klasikal sebesar $100 \%$. Siswa dikatakan tuntas apabila $\geq 75 \%$ siswa memperoleh nilai Kriteria Ketuntasan Minimal (KKM) sebesar $\geq 73$. Hal ini menunjukkan hasil belajar siswa dikatakan tuntas secara klasikal dan mengalami peningkatan dari siklus II. Hasil belajar siswa pada siklus III membuktikan bahwa siswa sudah memahami materi yang dipelajari dan mampu menjawab soal tes pengetahuan.

Peningkatan hasil belajar pengetahuan pada siklus I sampai siklus III menjelaskan bagaimana penguasaan dan pemahaman siswa terhadap materi yang diajarkan.

Berdasarkan uraian diatas, maka dapat kita lihat bahwa penerapan model Discovery Learning dapat meningkatkan hasil belajar siswa pada ranah pengetahuan. Hasil penelitian ini didukung oleh [15] yang menyimpulkan bahwa melalui penerapan model Discovery Learning dapat meningkatkan hasil belajar.

\section{Kesimpulan dan Saran}

\subsection{Kesimpulan}

Penerapan model Discovery Learning dapat meningkatkan aktivitas belajar, keterampilan proses sains dan hasil belajar siswa pada konsep usaha dan energi di kelas $\mathrm{X}$ IPA 3 SMAN 10 Kota Bengkulu. Pada siklus I rata-rata skor aktivitas belajar siswa yaitu 24 termasuk dalam kategori cukup, siklus II dan III rata-rata skor aktivitas belajar siswa yaitu 28 dan 34 termasuk dalam kategori baik. Kemudian rata-rata persentase pencapaian kompetensi keterampilan proses sains pada indikator mengajukan pertanyaan, merumuskan hipotesis, merencanakan percobaan, menafsirkan dan berkomunikasi yang paling tinggi yaitu indikator mengajukan pertanyaan. Selanjutnya Pada siklus I daya serap klasikal yaitu 70,5 \% dan ketuntasan belajar klasikal sebesar 63,33 \% dikatakan belum tuntas, pada siklus II daya serap klasikal yaitu 76,5\% dan ketuntasan belajar klasikal sebesar $80 \%$ dikatakan tuntas, dan pada siklus III daya serap klasikal yaitu 83,6 dan ketuntasan belajar klasikal sebesar $100 \%$ dikatakan tuntas.

\subsection{Saran}

Hendaknya guru dapat mengatur waktu selama pelaksanaan pembelajaran agar pembelajaran dapat berjalan dengan optimal. Dalam pembagian kelompok praktikum sebaiknya hanya empat sampai lima orang dalam satu kelompok, agar siswa dapat terlibat aktif dalam melakukan praktikum.

\section{DAFTAR PUSTAKA}

[1] Putri, U. D., \& Suliyanah. (2015). Penerapan pendekatan Saintifik Melalui Model Discovery Learning pada Materi Fluida Statis untuk Meningkatkan Hasil Belajar Siswa Di Kelas X SMA Negeri 8 Surabaya. Jurnal Inovasi Pendidikan Fisika (JIPF), 150-155.

[2] Susanti, E., Jamhari, M., \& Suleman, s. M. (2016). Pengaruh Model pembelajaran Discovery Learning terhadap Keterampilan Proses Sains dan Hasil Belajar Siswa Kelas VIII Tentang IPA SMP Advent Palu. Jurnal Sains dan Teknologi Tadulako, $36-41$. 
[3] Toharudin, U., Hendrawati, S., \& Rustaman , A. (2011). Membangun Literasi Sains Peserta Didik. Bandung: Humaniora.

[4] Hosnan, M. (2014). Pendekatan Saintifik dan Kontekstual dalam Pembelajaran Abad 21. Bogor: Ghalia Indonesia.

[5] Arikunto, S., Suhardjono, \& Supardi. (2009). Penelitian Tindakan Kelas. Jakarta : Bumi Aksara.

[6] Juhji. (2016). Peningkatan Keterampilan Proses Sains Siswa Melalui Pendekatan Inkuiri Terbimbing. Jurnal Penelitian dan Pembelajaran IPA, 58-70.

[7] Purwanto, A. (2009). Penerapan Media Jejaring Sosial Facebook pada Mata Kuliah Termodinamika. Jurnal Exacta, 49-55.

[8] Widiyanto, M. A. (2013). Statistika Terapan. Jakarta: PT Elex Media Komputindo.

[9] Hamalik , O. (2009). Dasar-dasar Pengembangan Kurikulum. Bandung: Remaja Rosdakarya.

[10] Istiana , G. A., Catur S, A. N., \& Sukarjo, J. (2015). Penerapan Model Pembelajaran Discovery Learning untuk Meningkatkan Aktivitas dan Prestasi Belajar Pokok Bahasan Larutan Penyangga pada Siswa Kelas XI IPA Semester II SMA Negeri 1 Ngemplak Tahun Pelajaran 2013/2014. Jurnal Pendidikan Kimia (JPK), 65-73.

[11] Astra, I. M., \& Wahidah, R. S. (2017). Peningkatan Keterampilan Proses Sains Peserta Didik Melalui Model Guided Discovery Leaning Kelas XI pada Materi Suhu dan Kalor. Jurnal Penelitian \& Pengembangan Pendidikan Fisika, 181-190.

[12] Sati, D. L. (2017). Penerapan Model Discovery Learning untuk Meningkatkan Hasil Belajar Kognitif dan Keterampilan Proses Sains Di kelas VII B SMP Negeri 10 Kota Bengkulu. Skripsi FKIP Universitas Bengkulu: Tidak diterbitkan.

[13] Resiningtias, M. (2016). Penerapan Model Discovery Learning untuk Meningkatkan Hasil Belajar dan Keterampilan Proses Sains Siswa Kelas VII A SMPN 2 Kota Bengkulu. Skripsi FKIP Universitas Bengkulu: Tidak diterbitkan.

[14] Kunandar. (2013). Penilaian Autentik (Penilaian HAsil Belajar Peserta Didik Berdasarkan Kurikulum 2013) Suatu pendekatan Praktis Disertai dengan Contoh. jakarta: RajaGrafindo Persada.

[15] Iswati, D. A., \& Dwikoranto. (2015). Penerapan Model Pembelajaran Discovery Learning Terhadap Hasil Belajar Siswa pada Materi Fluida Statis Di SMAN 1 Mojosari. Jurnal Inovasi Pendidikan Fisika (JIPF), 83-87. 